Association for Information Systems AIS Electronic Library (AISeL)

International Research Workshop on IT Project International Research Workshop on IT Project

Management $2007 \quad$ Management (IRWITPM)

December 2007

\title{
Top Management Support: Mantra or Necessity?
}

Raymond Young

Macquarie University

Ernest Jordan

Macquarie University

Follow this and additional works at: http://aisel.aisnet.org/irwitpm2007

\section{Recommended Citation}

Young, Raymond and Jordan, Ernest, "Top Management Support: Mantra or Necessity?" (2007). International Research Workshop on IT Project Management 2007. 13.

http://aisel.aisnet.org/irwitpm2007/13

This material is brought to you by the International Research Workshop on IT Project Management (IRWITPM) at AIS Electronic Library (AISeL). It has been accepted for inclusion in International Research Workshop on IT Project Management 2007 by an authorized administrator of AIS Electronic Library (AISeL). For more information, please contact elibrary@aisnet.org. 


\section{Top Management Support: Mantra or Necessity?}

\author{
Raymond Young \\ Macquarie University \\ ryoung@efs.mq.edu.au
}

\author{
Ernest Jordan \\ Macquarie University \\ ernest.jordan@mgsm.edu.au
}

\section{ABSTRACT}

This research provides substantial evidence that top management support is the most important critical success factor for project success and is not simply one of many factors. The finding is justified in the context of the project management literature and the IT factor research. There are significant implications for practice because it appears that the conventional project management and technical advice has less impact on success than previously thought. Boards and top managers may have to personally accept that they have more influence on whether a project succeeds or fails.

\section{Keywords}

Top management support, critical success factor, project success, project failure, IT/business project, organisational change, project champion

\section{INTRODUCTION}

The importance of top management support (TMS) has long been recognised in the IT literature (Doll 1985; Garrity 1963; Lederer et al. 1988; Rockart et al. 1984). However, practitioners and researchers alike, have focussed their attention on factors they can more directly control (Schmidt et al. 2001) and appear to only pay lip-service to TMS (Emery 1990; Jarvenpaa et al. 1991).

Prescriptions for TMS are not well developed (Bassellier et al. 1998). Some impose very demanding requirements for top management resources in order to improve technical quality or user satisfaction (Brandon 1970; Dinter 1971; Doll 1985; Izzo 1987) goals of little direct interest to top managers. Other prescriptions for communication, enthusiasm, involvement and participation appear to be little more than exhortation (Emery 1990; Izzo 1987; Lederer et al. 1988; Schmitt et al. 1978). TMS is generally promoted as being inherently good (Mähring 2002) but there is clear evidence that too much TMS can be dysfunctional and lead to failure (Collins et al. 1997; Keil 1995).

Projects can succeed without following the general prescriptions for TMS and others can fail while following all the common prescriptions (Standards Australia 2006). As a result, the advice for top managers lacks credibility. However, few would doubt the need for TMS (Markus 1981) and TMS is consistently recognised as a critical success factor (Schmidt et al. 2001).

The problem is that current prescriptions are practitioner-led and mantra-like in their call for TMS. Top managers have the freedom to provide or withhold their support but current prescriptions are failing to have any significant influence on their behaviour. This paper will therefore make a significant realignment in approach and reconsider the issue of TMS from the perspective of the most relevant stakeholders (boards and top managers). It has conceptualised this problem as two related issues (1) How important is TMS and (2) what constitutes effective TMS, but for reasons of length will only address the first and more fundamental of these two issues. If top managers are not convinced of the importance of TMS, there is very little point defining TMS in more detail. The second issue will be addressed in a future paper and this paper will simply summarise the range of behaviours that might constitute TMS. TMS is too poorly understood to limit any initial study with what might turn out to be a narrow definition and the full range of conceptions will be used to explore how important TMS might be.

To manage scope the paper will study TMS in the context of $\mathrm{IT}^{7}$ projects - an issue demanding board level attention because of the high levels of investment and the strategic consequences of failure (Clegg et al. 1997; KPMG 2005).

\section{LITERATURE REVIEW}

\section{Key Insights from the Project literature}

Over time, an enormous range of methodologies have been developed to address technical issues and specific failure factors (Boehm 1991; Lyytinen 1987). Their adoption has increased steadily over many decades but their widespread use has not led to a corresponding reduction in IT project failure rates (Clegg et al. 1997; Sauer 1999). Some have found these common approaches to be of little practical utility in coping with IT problems (Kraemer et al. 1986) and others complain they are

\footnotetext{
${ }^{7}$ To follow the language of the board, this paper will use the term IT to mean both IS and IT.
} 
untested against objective measures of performance such as profitability (Bussen et al. 1997; Checkland 1981; Strassmann 1995). It has long been suggested that IT projects fail more because of organisational than technical issues (Lucas 1975; Sauer 1999). However the majority of IT researchers and practitioners "persist with technological or engineering conceptions of the problem" (Currie et al. 1999) and organisations are reported to be consistently repeating the same mistakes and wasting billions of dollars every year (Collins et al. 1997; Young 2006a).

A significant barrier to progress is the lack of generally accepted definitions of success or failure (Sauer 1993; Seddon et al. 1999). Few explicitly recognise the fundamental difference between project success (the realisation of business benefits) and project management success (on-time on-budget to specification) (Baccarini 1999; de Wit 1985). The result is that the number of success stories (however defined) is reported to be almost twice the number of failures (Falconer et al. 1999; Rocheleau 2000). A project success perspective suggests the opposite situation is more likely to be true (Clegg et al. 1997; Standish 1999; Standish 2003; Willcocks et al. 1994; Young 2006b)

Project management success has been shown not to strongly relate to project success (Markus et al. 1994; Markus et al. 2000). Project management success is an operational concern generally of little interest to top managers (Crawford 2005; Thomas et al. 2002) because it focuses on completing a project on-time and within-budget. In contrast project success focuses on whether the right benefits are being targeted and realised (Hinton et al. 1996). This directly relates to effective corporate governance at a top management level and a fundamental objective of corporate governance is to target above-average performance (BRW 2003; Hewson 2003; Hilmer 1993).

A related insight is that business participants need to focus on 'change agentry' and benefits management (Markus 1996; Ward et al. 1996). It takes a relatively long time to realise benefits from an IT investment thus the majority of the benefits of an IT investment are realised after a project team has disbanded (Cooke-Davies 2002; Yardley 2002). This implies project success must be the primary responsibility of business managers rather than project managers. Evidence suggests that if top management can sustain a vision of what will be achieved (over 1-8 years), they will better be able to tolerate a period of initial decreased performance and realise more benefits (Brynjolfsson et al. 1998).

However, these insights are seldom reflected in practice. For decades the number one concern of IT directors has been to meet project deadlines or some other goal (Brancheau et al. 1996; Dickson et al. 1984; Grindley 1995; Hartog et al. 1986; Luftman et al. 2006; Luftman et al. 2004) and top managers have largely not focussed on the realisation of benefits (DellaVecchia et al. 2007; KPMG 2005).

Common practice is better represented by the large body of research trying to identify factors leading to project success or failure (Keil et al. 1998; Nelson 2007; Schmidt et al. 2001). The conventional wisdom recognises TMS to be one of many CSFs but the first two insights suggests that this understanding may underestimate its importance. At the very least, the continued high failure rates strongly suggests that the common practice has not captured the essence of the problem.

To re-examine the issue, the Standish Group's (1996) list of failure factors will be adopted to represent the conventional wisdom. They are widely cited and consistent with academic research. However, to recognise the likely deficiencies in common practice, the original list of ten CSFs will be condensed into a list of more manageable concepts. The intention has been to capture similar themes and more easily recognise how project success or failure might be attributable more to organisational than technical issues. They are presented below according to the importance suggested by the Standish weightings (in brackets).

- Project methodologies (35): Clear statement of requirements (15), Proper planning (11), smaller project milestones (6)

- User (25): User involvement (19), ownership (6)

- $\operatorname{TMS}(16)$

- High level planning (13): realistic expectations (10), clear vision \& objectives (3)

- Project staff (11): Competent (8), focussed and hard working (3)

It is suggested that future research into IT project failure would do well to also recognise that something must be missing from our understanding and adopt a similar strategy - summarising existing knowledge rather than have too much detail.

\section{Top management support}

The literature on top management support parallels the project management literature but tends not to be so rich. The earliest recommendations from Garrity (1963) are not widely cited but stand out for the exposition of the key themes to be found in this literature:

1. Devote time to the [IT] program in proportion to its cost and potential 
2. Review plans

3. Follow up on results

4. Facilitate "the management problems involved with integrating computer systems with the management process of the business".

Some researchers have built on the first theme to encourage top management actively to identify and focus investment on the most strategic areas for the organisation (Doll et al. 1987; Lane 1985; O'Toole et al. 1966; Rockart et al. 1984). Others have developed the fourth theme and emphasised the need to ensure operational managers take responsibility for delivering the anticipated benefits (Henderson 1990; Rockart 1988). Sharma and Yetton (2003) highlight the need for "management metastructuration". They found that as task interdependence increases in a project, institutional context present increased barriers which can only be overcome by mechanisms such as new support structures, new performance control systems, new coordination mechanisms and changes to performance goals.

Only Beath (1991) seems to have made any significant advance on Garrity's four themes. She has found [top managers as] project champions to sometimes be the most important antecedent to a successful implementation because of their skills as in bringing about organisational change. Morton (1983) identifies their specific skills to be mobilizing public opinion, resolving stakeholder conflicts and winning the hearts and minds of the project team. Little has been done to systematically capture this insight and even today articles are accepted in leading journals that find top management support for change as a lesson learned (Rangananathan et al. 2004).

In response to the issue of multiple definitions of success or failure, the literature on TMS has been summarised in Figure 1 below by scope and by success measure. Articles have been grouped according to whether they focus on IT in general, IT projects or the IT function (Delone et al. 2003) and according to whether they emphasise technical/project management success, user satisfaction or the realisation of benefits (Seddon et al. 2002; Seddon et al. 1999). Details to support this classification are shown in Appendix 1.

\begin{tabular}{|c|c|c|c|}
\hline \multirow{5}{*}{$\begin{array}{l}\text { Realisation of } \\
\infty \quad \text { benefits }\end{array}$} & \multicolumn{3}{|c|}{ Scope of TMS advice } \\
\hline & IT in general & IT Projects & \multirow{8}{*}{ IT Function } \\
\hline & (Doll et al. 1987; Garrity 1963; & (Adams 1972; Delone 1988; McGolpin & \\
\hline & Henderson 1990; Lane 1985; O'Toole & et al. 1997; Reich et al. 1990; Rochleau & \\
\hline & et al. 1966; Rockart 1988; Rockart et & 2000; Rockwell 1968) & \\
\hline \multirow{4}{*}{$\begin{array}{l}\text { User } \\
\text { satisfaction } \\
\text { Technical or } \\
\text { project } \\
\text { management }\end{array}$} & (Bassellier et al. 1998; Dinter 1971; & (Mähring 2002; Markus 1981; Sharma & \\
\hline & Freeman 1969; Jarvenpaa et al. 1991) & et al. 2003) & \\
\hline & & (Emery 1990; Schmitt et al. 1978) & \\
\hline & $\begin{array}{l}\text { (Brandon 1970; Doll 1985; Izzo 1987; } \\
\text { Lederer et al. 1988) }\end{array}$ & & \\
\hline
\end{tabular}

Table 3: Summary of advice for top managers by scope and success criteria

Of the articles in the IT literature that offer advice for top managers, some focus on IT in general and some focus on IT projects. Quite sensibly, none focus on the IT function because this is a specialist rather than a top management concern. However, many articles adopt criterion for success that are not of direct interest to top managers.

The advice that exists is often IT focussed and not linked to any causal model of how IT delivers value to an organisation e.g. (Akkermans et al. 2002; Grover et al. 2000; Markus 2000; McGolpin et al. 1997; Reich et al. 1990; Sharma et al. 2003; Soh et al. 1995; Yardley 2002).

\section{Summary of Literature}

The literature review suggests the reason why the call for TMS seems to be ignored (Huff et al. 2006) is that top managers often have no easy way to recognise good advice. A key insight from the project management literature consistent with the demands of corporate governance is that top managers must focus on the realisation of benefits, but the research on TMS does not focus on the realisation of benefits. It is possible that the problem has arisen because it has not been in the technical experts' interest to emphasise the role of top management because it would result in a loss of power (Smyrk 2002; Thomsett 1989).

The implications are very significant. Boards and top management 'are dependent on the advice they receive' (Hampel 1998). In one study, a senior board member made the assessment that "with technocrats, the only three things you can be sure of are: 
nothing would get finished on time, it would always cost vastly more than predicted and it would never do what it was promised to do" (Young et al. 2002b). While this is extreme, it is a view that is not unusual and it is significant that it does not differentiate between project management and project success. The quote supports the assertion that future advice must be credible.

Generally only lip-service is paid to the need for TMS, yet there are still many successes. It would be inappropriate to suggest major changes in practice unless there is stronger evidence that the current practice is wrong in its emphasis. Therefore there is a need to evaluate whether the effort to challenge the status quo is justified.

This paper proposes to examine the issue by evaluating the importance of TMS against the other commonly recognised CSFs for project success. Project success will be defined to be consistent with corporate governance objectives - 'when [promised] benefits are delivered and above average performance is achieved, taking into account of risk'. The study will not attempt to repeat past factor research studies, but instead use CSFs as a lens to understand the complex organisational phenomena surrounding IT projects.

\section{METHODOLOGY}

The question of how important TMS is for project success will be studied through descriptive case studies. The research has the pragmatic goal of influencing behaviour (Goles et al. 2000; Tashakkori et al. 2003), and descriptive case studies are recognised to be an effective means of communicating contributions to practice (Benbasat et al. 1999).

TMS deals with organisational phenomena where the boundaries between the phenomena and context are not clearly evident. Hence the case study has a distinct advantage over alternatives such as surveys, archival research, historical analysis and experiments because there is a 'how' or 'why' question being asked about a contemporary set of events over which the investigator has little or no control (Yin 2003).

The research used a multiple-case study design following a replication logic (Yin 2003). Information richness was maximised by choosing both average organisations and exemplary organisations (Patton 1990). The unit of analysis was a single IT project in the context of the benefits delivered to an organisation.

For rigour, five cases in total were conducted with 59 interviews in total (Perry 1998). Interviewees always included project sponsors, top managers, members of the project team and stakeholders from multiple levels within the organisation. The elapsed time between the first case study and the last case study was two years and seven months. The guiding principle was to try to complete one case study at a time because adequate time needed to be spent in the field and time needed to be available to reflect and refine the research and interview questions and consider theories in use (Klein et al. 1999). It was found that theoretical saturation was reached after the first four cases (Eisenhardt 1989).

Case study organisations were identified through a collaboration partner Standards Australia, the Australian national Standard-setting body. A specific working group (IT-30) was established to focus on IT project governance with representation from 49 industry organisations consisting of 170 IT practitioners, industry representatives and academics. Through a Delphi survey, this group identified seven exemplary organisations three of which were able and willing to participate in the research. Two other organisations were selected on the basis of access to represent more typical organisations. One of these was a pilot case to develop the case study protocol. The other was a test case to validate the importance of top management support (in a project that did not require organisational change). Ease of access is a reasonable selection criterion because TMS has consistently been found to be important and it should not matter which organisations are selected.

Rigour was maintained by having multiple sources of evidence (interviews, project documentation, observation), a standard interview instrument (Appendix 2), interview documentation (transcripts, second interviewers, field notes) and the intensive participation of key informants.

In all cases, at least one key informant would have provided feedback to the researcher several times a day while he was on site. In each case there was no fewer than three and there were often more than six active reviewers of both the draft and final versions of the case study report. Typically reviewers would include at least one senior manager, project manager and IT specialist. All the case study organisations were very image conscious and all but one chose to remain anonymous. This anonymity and the extensive periods given for feedback provide some assurance that the cases are credible.

The case analysis will follow the general strategy of developing a chronological case history to describe the key events and decisions then evaluate how well each CSF explains the outcomes. The analysis will consider each case individually and use a cross case analysis to build a more complete explanation. 
This research has guarded itself against biases by subjecting itself to critical review in three main ways. Firstly case study participants reviewed the cases. Secondly the cases were published commercially (Standards Australia 2006) after being reviewed by approximately 25 people including members of the Standards Australia working group. Thirdly the cases and the explanations as they were iteratively developed were presented for feedback at academic conferences (Young 2003; Young et al. 2002a; Young et al. 2002b; Young et al. 2003).

\section{RESULTS}

Case study vignettes of the research are presented below. Full versions of the case histories have been published (Standards Australia 2006).

The first two cases are of 'typical' organisations. The subsequent three are of organisations identified by the 170 members of the Standards Australia working group as being more successful than most with IT. Apart from the Australian Bureau of Statistics, all the cases have been anonymised, although it can be revealed the other two exemplary organisations were a private sector investment bank and a public sector scientific organisation.

\section{TechServ - failed, no ownership.}

Margins had been declining for many years and the TechServ project had to be undertaken to realise the benefits of a strategic merger. The objective was to integrate the core operational systems to standardise the business processes, to rationalise staff and reduce the cost structure.

The project only managed IT considerations and failed to take into account business process dependencies. The systems were integrated but two critical functions were lost. One prevented TechServ from producing invoices and revenue dropped by $25 \%$ for several months until the problem was fixed. The other function was very important for customer satisfaction. The sudden loss of this function affected TechServ's business reputation. TechServ remained on the bottom 5 of its industry for customer service for the next five years.

The main reason the project failed was because political criteria determined the selection of the system. The responsibility for the implementation was delegated to an external project manager without an official senior management sponsor. IT staff raised many issues but senior managers did not explore the implications and failed to resolve the issues.

\section{TechMedia $-\mathbf{6 0} \%$ success, weak project governance}

Y2K provided an opportunity for TechMedia to upgrade to an ERP system. It was planned to implement the current version of the ERP to meet compliance and then to implement the next release as soon as it was available because it had the functionality needed to underpin future growth. The expected benefits were conservatively estimated to be $\$ 6$ million.

It was claimed to be the fastest implementation of this ERP in the world. However, only $\$ 3$ million of anticipated benefits were realised. The failure to meet expectations has undermined the business case for the next release of the ERP and it has not been implemented.

Issues relating to process and organisational change were not adequately resolved. Management as a whole did not understand that benefits flow more from changes to business processes than from system implementation alone. Senior managers itemised the specific benefits that would be realised in their functional area but did not follow through and authorise the process changes needed to realise the benefits. Many issues were escalated to the steering committee and above. It was known that one senior manager was causing particular difficulties, but no one with sufficient authority intervened to resolve the issues.

\section{The ABS - a W.I.P., sponsor moved on.}

The project management achievements in the Australian Bureau of Statistics (ABS) are among the best in Australia. In anticipation of future organisational stresses, a project management framework (PMF) was implemented to raise the standard. The objective of the PMF was to formalise project management practices, reduce risk, capture knowledge and increase the reliability of realising project benefits.

The PMF infrastructure was implemented and training delivered. As a result the ABS is one of the few organisations in Australia that has a widespread understanding of the difference between outputs (produced by project management) and outcomes (that are the benefits of projects). However the project sponsor left before all the expected benefits were realised and the project lost momentum. All major projects now manage risk through PMF but formal adoption of PMF is relatively low in other types of projects and there still tends to be a focus on outputs rather than outcomes. 
The PMF is a work in progress. A proposal has been made to further enhance functionality for benefits management (rather than just project management) and to make it more scaleable for different sized projects.

\section{The Agency - on-time, on budget, but a success?}

An ERP was implemented to comply with requirements for accrual accounting standards and also to provide management information. The project had to overcome low morale and political interference.

A very understaffed and junior project team were inspired by a high level of senior management support to bring the project in on-time and on-budget. New functionality allowed for both accrual accounting and additional management reports. In terms of compliance the project was a success. However three years after the implementation, the amount of management information is less than what was previously available.

"The jury is still out" on whether the project was a success or not. It met the primary objective of the senior management team but did not meet all the formal objectives of the business case. The over-riding concern of the senior management team had actually been to avoid a failure and the project sponsor had focussed more on the first formal objective, compliance. The second objective, management information, was never emphasised by the senior management team and subsequently was not realised.

\section{SkyHigh - 96-98\% success, a passion to succeed.}

A new (ERP) system was implemented to overcome the stresses of very rapid growth and provide high quality information to pass audit requirements and maintain investor confidence.

Many staff changes were needed and almost every business process had to be changed. A detailed project plan was prepared and incentives were linked to the success of the project.

SkyHigh has a strong risk management culture. Decisive governance by the project sponsor ensured top managers were rapidly made aware of issues (outside the authority of the project team) and that they were resolved quickly. Top managers had a very clear understanding of what was wanted and a detailed awareness of the business processes provided a common language for risk assessment and decision-making.

The new system was implemented and there is now a high degree of confidence in financial and operational information.

\section{DISCUSSION}

The discussion will evaluate which CSF was most important for project success. Project success is defined to be when expected benefits are delivered and above average performance is achieved, taking into account of risk.

Analysis will follow the tenets of the pragmatic paradigm (Tashakkori et al. 2003) and deliberately favour the values of the board and top management stakeholder group over others. This is justified because the call for TMS is clearly focussed on this key audience. It is also consistent with calls by leading IT researchers to increase research relevance for key stakeholder audiences.(Davenport et al. 1999; Goles et al. 2000; Lee 1999).

Five CSFs were proposed to evaluate the degree to which top management support is the most important factor for success. It is to be expected that all factors will be important, and the analysis is to determine (1) the degree to which one CSF might be more important than the others and (2) the interrelationship TMS might have with the other factors.

The guiding principles in the analysis will follow from the observation that the TechServ project failed, the SkyHigh project succeeded in almost every way, and the Agency, TechMedia, and ABS projects succeeded to lesser degrees. The implication is that if TechServ managers did or SkyHigh managers did not address a CSF, it is unlikely to be the most important CSF. If SkyHigh managers addressed a CSF and the Agency, TechMedia, ABS and TechServ managers did not, then it is likely to be very important. Variations on this theme are interpreted to assess the relative importance of a CSF.

\section{Individual Case Analysis}

Each case could either fully support (Full), partially support (Partial) or not support (No) the hypothesis that a CSF was the most important. TechServ the least successful project did not support project staff and high level planning as the most successful CSF because they were adequately addressed in the project but the project failed. TechMedia did not support project methodologies as the most important CSF because it was very well addressed but the project was only partially successful. The ABS did not support project staff as the most important CSF in a similar way but suggested TMS is the most important CSF because the project stalled when the project sponsor resigned. The Agency project allowed a similar conclusion to be made because it adequately addressed all the CSFs except top management support. SkyHigh the most successful project addressed every CSF well and could not be used to discriminate which factor was most important. 


\section{Cross Case Analysis}

A cross case comparison will allow us to determine whether a CSF is the most important. The analysis will follow Yin (2003) and interpret each case as a quasi-experiment to generalise against theory. The hypotheses to be tested will be whether one of the five CSFs is the most important.

\section{Project staff}

All projects had relatively competent focussed and hard working staff. The TechServ project failed while the others did not and the outcomes ranged from complete failure to complete success. Both TechServ and the Agency had a successful and a failing project using literally identical teams of staff. The conclusion is that project staff do not account for the differences in outcomes and cannot be the most important CSF.

\section{Project Methodology}

Both the TechServ and TechMedia projects followed quite detailed project plans. However neither could be considered very successful from a board perspective. The SkyHigh project followed a very detailed project plan and was an outstanding success. The Agency project had a poor project plan, but was relatively successful.

The SkyHigh project plan paid particular attention to anticipating and scheduling business process changes as part of the project. The SkyHigh project managed this upfront by recruiting better-trained staff and by planning the project around making process changes rather than minimising them. Any need to deviate from the project plan was rapidly recognised, escalated and resolved by the steering committee where possible and through other senior managers as necessary.

In contrast the Agency, which also started with under-skilled accounting staff, did not adequately customise the project plan to match the available resources and they had to make major changes. The initial Agency project plan was a source of conflict between the consultants and the project team rather than a source of comfort. It ended up omitting several major steps usually included for risk management (project sign offs, system testing) and revising the go-live date by several months to include more training than had originally been planned. This was bad from a project management perspective but it did not affect project success (benefits realisation).

The comparison suggests that project methodologies can be used effectively as a risk management tool but contrary to the conventional wisdom, they are not the most important CSF. Methodologies appear to be particularly useful for considering how resources will be managed to implement business process changes. These results support Dvir and Lechler's (2004) finding that it is not the plan itself that is important, but the ability to change the plan to react to issues as they are realised. Complexity makes it almost impossible to anticipate all the issues, but a thorough consideration of the business process reduces the number of major changes needed in the plan.

\section{High Level Planning}

The TechServ project had a very clear high level plan built around strategic imperatives and very realistic expectations (because a harder project had already succeeded) yet the project failed. The TechMedia project had even more detailed high level plans and although it did not fail outright, it was not overly successful in meeting its promised outcomes.

Only in the case of the ABS project is it possible that better outcomes might have been realised through a more formalised high-level plan. However in this case a more formalised high level plan was only likely to be helpful if the ABS board had used it to monitor the outcomes.

The conclusion is that high-level project planning is not likely to be the most important CSF.

\section{User Involvement and Ownership}

User involvement and ownership was present in varying degrees in the different projects. The SkyHigh project had high levels of ownership. SkyHigh showed that user involvement adds value by ensuring completeness in the list of requirements. It also showed that users can sometimes resist change and insist on inefficient processes. The implication is that it is more important for the project manager and the project sponsor to lead discussions to determine whether user requirements are critical, "nice-to-have" or "wish-list" items.

A comparison with the other cases strengthens this interpretation. The TechServ project had low levels of ownership and no user involvement. The TechServ project probably would have benefited from more user awareness of the issues. The Agency project was unable to solicit much user involvement and suffered in the implementation partly because the expectations were not well managed. The TechMedia project had mixed levels of ownership but quite extensive user involvement. However 
user input was relatively ineffective because their suggestions required process and organisational changes that the senior managers did not prioritise or authorise. The ABS project was leading edge and user involvement was unlikely to have contributed anything to the requirements. At most it could have helped anticipate difficulties in adoption, but it would have been difficult for users to anticipate the final product and add value.

The conclusion is that ownership is important for quality user involvement and user involvement is helpful to solicit requirements and as a process to manage expectations. However it is helpful only when the project manager and senior managers are transparent in resolving issues and conflicts between different user priorities. User involvement is therefore unlikely to be the most important CSF.

\section{Top Management Support}

Top management support appeared to be important in every case and its importance was most clearly seen when it was absent. In the TechServ project there was no sponsor and the project was a complete failure. In the ABS project the sponsor left half way through the project and the project stalled. In the TechMedia project top management failed to authorise process changes and only half the promised benefits were realised (and perhaps only a quarter of the potential benefits). The Agency project had strong support in some areas and was partially successful. The SkyHigh project had outstanding support in all areas and was an outstanding success.

The SkyHigh project illustrated very clearly that the main decisions senior managers (including the sponsor) had to make were related to resolving unanticipated process changes. The complexity of process inter-relationships made it difficult to anticipate every issue. The success of the project required senior managers to make organisational or process changes to mitigate risks or to accept risks outside the authority of the project team.

The TechMedia project illustrated the same lessons in the negative sense of what needed to occur. Risks were identified but unresolved at the steering committee level throughout the course of the project. Recommendations requiring process or organisational change were proposed but were never authorised. The sponsor did not have authority to influence his peers and the CEO did not intervene until it was too late. The risks eventuated and the planned benefits were compromised as predicted. The situation was similar with the Agency and ABS projects.

The TechServ project was dysfunctional in senior management's consideration of process change. No effort was made to understand the issues and risks from a business perspective and the senior managers paid for their negligence personally when they lost their salary bonuses after the project failed.

The results therefore support the conclusion that TMS is the most important CSF.

\section{Summary of discussion}

The cross-case analysis is summarised in Table 2. The CSFs are presented in descending order of support. It is significant that the order is very different to that predicted by the Standish weightings (shown in the left hand column). The implication is that the conventional wisdom is misguided to emphasise project methodologies and user involvement over TMS.

\begin{tabular}{|ll|c|c|c|c|c|}
\hline CSF & T-Serv & T-Media & ABS & Agency & SkyHigh \\
\hline 3 & $\begin{array}{l}\text { Top management } \\
\text { support }\end{array}$ & Full & Full & Full & Full & Full \\
\hline 2 & $\begin{array}{l}\text { User } \\
\text { involvement }\end{array}$ & Partial & Partial & Partial & Partial & Partial \\
\hline 4 & $\begin{array}{l}\text { High level } \\
\text { project planning }\end{array}$ & No & Partial & Partial & Partial & Full \\
\hline 1 & $\begin{array}{l}\text { Project } \\
\text { methodologies }\end{array}$ & Partial & No & - & Partial & Full \\
\hline 5 & Project staff & No & Partial & No & Partial & Full \\
\hline
\end{tabular}

Table 4: Degree of Support that a CSF is the most important (Key in text)

\section{CONCLUSION}

This research provides substantial evidence that TMS is not simply one of many CSFs needed for project success, but is the most important CSF. It supports an earlier suggestion that TMS is a 'meta-factor' that encompasses other CSFs (Poon 2001). 
This is a major finding because it refutes the weightings suggested by Standish (1996) and by implication much of the current wisdom and practice.

The research does not support user involvement or high level project planning as the most important success factor. Highlevel plans appear to be important if they are used to reinforce the motivations and beliefs of an executive project sponsor. Ownership and user involvement appear to be useful in soliciting requirements, but their real value appears to be when top managers use the process of gathering user requirements to manage expectations. It seems to be very important that top managers are transparent in resolving issues and conflicts between different user priorities.

The research rejects project methodologies as the most important factor for project success. This is a major finding that challenges the conventional wisdom and the emphasis on project methodologies (clear statement of requirements, proper planning, smaller project milestones). It confirms that project management is rightly considered by senior managers to be relatively unimportant (Crawford 2005; Thomas et al. 2002). Project methodologies are needed to consider in detail how to implement business process changes, but they are limited because complexity makes it impossible to anticipate all the issues. It is not the plan itself that is important, but the ability to change the plan to react to issues as they are realised. This is a project governance rather than a project management issue.

The research rejects competent, focussed and hard working project staff as the most important condition for project success. Project staff provided the least explanatory power for success or failure. It is suggested that once a minimum level of competency has been recruited, success is almost entirely determined by the quality of TMS.

The conclusion is that when success is defined in terms that are consistent with corporate governance goals and the insights in the project management literature, the advice in the IT and project management literature for top managers is largely misguided. Organisations do not invest in IT projects to simply be on time, meet budgets or satisfy users; they invest in projects to realise business benefits. It is incorrect to assume one leads to the other. Realisation of business benefits often requires significant organisational change and this cannot be the primary responsibility of project managers.

These findings have informed the development of Australian Standard AS8015 (Corporate Governance of IT) which in turn has been ratified for fast-track adoption by the International Standards Organisation. The findings are also consistent with recent developments in this area (Kohli et al. 2004; Peppard et al. 2007) and an entire special issue of the International Journal of Project Management (Volume 24, Issue 8 ). There are significant implications for board, senior management and project management practice and academia:

1. Boards and top managers may have to accept that they personally have the most influence on whether a project succeeds or fails.

2. Boards, top managers and their advisors may have to accept that the current expert advice has less impact on success than previously believed because a business rather than a project/technical focus is required.

3. Project managers must recognise the limitations of project methodologies and allow projects to focus on project rather than project management success even though they cannot be accountable for the realisation of outcomes/benefits.

4. The AIS SIG for Project Management working group developing an IT project management curriculum and other owners of project management standards (PMI, APM, PRINCE2) may need to be modified to allow for or incorporate the findings by addressing top managers specifically.

Considerations of length prevent a fuller exploration of what constitutes good advice for TMS. This is worthy of further research. The change management and project champion literatures appear to have much to offer given that so much of the value of IT seems to revolve around organisational change. It is also suggested that the analysis in this paper be repeated against more case studies to evaluate the extent to which the findings can be generalised.

\section{APPENDIX 1 - PRESCRIPTIONS FOR TMS}

\begin{tabular}{|l|l|}
\hline Author(s) & Prescription(s) for top management \\
\hline 1. Garrity (1963) & $\begin{array}{l}\text { Top management should spend time reviewing the plans and programs in } \\
\text { proportion to the costs and potential ... and then follow up on the results } \\
\text { achieved. They must direct operating management to be actively involved } \\
\text { and be accountable for the results achieved. The computer's challenge to top } \\
\text { management is that they must direct, manage and lead if profits are to result } \\
\text { and their assessment of the potential is the key. }\end{array}$ \\
\hline
\end{tabular}




\begin{tabular}{|c|c|}
\hline Author(s) & Prescription(s) for top management \\
\hline $\begin{array}{l}\text { 2. O'Toole and O'Toole } \\
\text { (1966) }\end{array}$ & $\begin{array}{l}\text { Policies and objectives to be set at the highest level to align with forward } \\
\text { planning for the whole company. "Hard decisions" may have to be made } \\
\text { because the most effective use of EDP will require some radical changes in } \\
\text { organization, lines of communication and control. }\end{array}$ \\
\hline $\begin{array}{l}\text { 3. Rockart and } \\
\text { Crescenzi (1984) }\end{array}$ & $\begin{array}{l}\text { Top management should direct effort by clarifying the business objectives, } \\
\text { the critical success factors and the key decisions that should be supported by } \\
\text { information systems. They should also stay actively involved in the process } \\
\text { of prototyping and developing the information systems because precise } \\
\text { knowledge of what information is required is seldom clear in the early stages } \\
\text { and participation produces the further insights needed to develop a } \\
\text { successful system. }\end{array}$ \\
\hline 4. Lane (1985) & $\begin{array}{l}\text { Integrate IT planning into the strategic planning process. Understand how } \\
\text { the significance of different types of technology to the success of the } \\
\text { organisation and take into account competitive IT capabilities / initiatives } \\
\text { when setting IT investment priorities. Have the courage to invest in needed } \\
\text { technology changes. }\end{array}$ \\
\hline $\begin{array}{ll}\text { 5. Doll and } \\
\text { Vonderembse (1987) }\end{array}$ & $\begin{array}{l}\text { Understand how IT will have strategic impact (vs simple operational } \\
\text { benefits) }\end{array}$ \\
\hline 6. Rockart (1988) & $\begin{array}{l}\text { Senior managers must assume responsibility for where to direct IT (in the } \\
\text { same way they direct staff and finances) and be involved with } \\
\text { implementation (which is better understood as transformation) because this } \\
\text { often requires significant organisational change (cutting across previously } \\
\text { independent divisions, functions, organisational sub-units) }\end{array}$ \\
\hline 7. Henderson (1990) & $\begin{array}{l}\text { Senior management, through the planning and monitoring process, must } \\
\text { encourage effective long term working relationships between information } \\
\text { technology personnel and line managers to realise specific mutual benefits. } \\
\text { Commitment to the relationships can be fostered formally by shared goals, } \\
\text { incentive systems and contracts but also depended on trust (established } \\
\text { through a track record of delivering on commitments), shared knowledge } \\
\text { and open communication through personal relationships. It is a challenge to } \\
\text { negotiate measures of the financial contribution of IT but it is important to } \\
\text { do so and focus on business impacts. }\end{array}$ \\
\hline
\end{tabular}

Table 5: TMS Research that emphasises delivery of benefits through IT in general. 


\begin{tabular}{|c|c|}
\hline Author(s) & Prescription(s) for top management \\
\hline 8. (Brandon 1970) & $\begin{array}{l}\text { Establish controls, perform long range planning, post installation audits, plan } \\
\text { for equipment }\end{array}$ \\
\hline 9. Doll (1985) & $\begin{array}{l}\text { Have written development plans, mutually agreed development priorities, } \\
\text { executive steering committees, system planing objectives (based on expected } \\
\text { pay-off potential and probability of success), long-term funding } \\
\text { commitments and project development policies (eg. operations sign off and } \\
\text { user documentation) }\end{array}$ \\
\hline 10. (Izzo 1987) & $\begin{array}{l}\text { Personally participate in IT management by guiding and shape business and } \\
\text { technology roles }\end{array}$ \\
\hline $\begin{array}{l}\text { 11. Lederer and } \\
\text { Mendelow (1988) }\end{array}$ & $\begin{array}{l}\text { Communicate regularly with IT management (objectives, business } \\
\text { environment, changing priorities) }\end{array}$ \\
\hline
\end{tabular}

Table 6: TMS Research that emphasises technical quality through IT in general.

\begin{tabular}{|l|l|}
\hline Author(s) & Prescription(s) for top management \\
\hline 12. Dinter (1971) & $\begin{array}{l}\text { Establish long range objectives for IT and stay informed (review all plans } \\
\text { and programs, follow up on results, insist project schedules are met and } \\
\text { takes corrective action as necessary, insist on cost-benefit analysis, makes } \\
\text { sure operating management participates actively and assumes major } \\
\text { responsibility for results, insist on high technical skills, emphasise company } \\
\text { commitment) }\end{array}$ \\
\hline $\begin{array}{l}\text { 13. Freeman (1969) } \\
\text { Take an active personal interest to understand the potential, demonstrate } \\
\text { excitement and show commitment by recruiting the best staff and staying } \\
\text { involved with initiatives. Educate management, keep users involved, and } \\
\text { have mechanisms to prioritise investments. }\end{array}$ \\
\hline $\begin{array}{l}\text { 14. Jarvenpaa and Ives } \\
\text { (1991) }\end{array}$ & $\begin{array}{l}\text { Be involved and participate to influence the progressive use of IT } \\
\text { of the importance of IT), participation (in IT planning, managing the IT } \\
\text { function \& operations), relationship with the CIO and provision of financial } \\
\text { resources. }\end{array}$ \\
\hline
\end{tabular}

Table 7: TMS Research that emphasises user satisfaction through IT in general 


\begin{tabular}{|l|l|}
\hline Author(s) & Prescription(s) for top management \\
\hline 16. (Rockwell 1968) & Begin at the top with the CEO \\
\hline 17. Adams (1972) & $\begin{array}{l}\text { Reward people to get the best proposals, assess benefits against costs and } \\
\text { risks, check the accuracy of estimates, monitor against project plans, get the } \\
\text { requisite talent, use new information and get results. }\end{array}$ \\
\hline 18. Delone (1988) & $\begin{array}{l}\text { CEO knowledge of computers and active ongoing involvement is the key to } \\
\text { success. Effectiveness does not improve with time, the key is for the CEO to } \\
\text { remain actively involved with which systems should be computerised and } \\
\text { how they should be computerised in a continuing ongoing process. }\end{array}$ \\
\hline $\begin{array}{l}\text { 19. Reich and Benbasat } \\
\text { (1990) }\end{array}$ & $\begin{array}{l}\text { The project champion must maintain continuity and support. Competitive } \\
\text { advantage takes no less than three years in the market and must have high } \\
\text { levels of adoption. IT implementation success and initial adoption are } \\
\text { necessary but not sufficient conditions for competitive advantage. }\end{array}$ \\
\hline $\begin{array}{l}\text { 20. McGolpin and Ward } \\
\text { (1997) }\end{array}$ & $\begin{array}{l}\text { Be involved with implementation as well as planning. Allocate responsibility } \\
\text { for benefit delivery and initiate strategic information systems in the context } \\
\text { of need for business change. }\end{array}$ \\
\hline 21. Rochleau (2000) & $\begin{array}{l}\text { Be "hands on" with decision-making, communication and evaluation. } \\
\text { Establish benchmarks and targets for change. Employ a disciplined process } \\
\text { in decision-making, risk management and ROI. Line managers should be } \\
\text { made to take control of the funding and direction of projects. }\end{array}$ \\
\hline
\end{tabular}

Table 8: TMS Research that emphasises delivery of benefits through IT projects.

\begin{tabular}{|l|l|}
\hline Author(s) & Prescription(s) for top management \\
\hline 22. Markus (1981) & $\begin{array}{l}\text { Resolve any conflicts between the new distribution of power implied by a } \\
\text { new system and the existing power structure. An information system can } \\
\text { alter power bases, patterns of communication, influence and decision- } \\
\text { making affecting prestige and status. }\end{array}$ \\
\hline 23. Mähring (2002) & $\begin{array}{l}\text { Direct intervention of top management should however be reserved for } \\
\text { extraordinary situations because it does not translate well into regular } \\
\text { organizational practice. Projects are subject to significant mutual influence } \\
\text { and co-dependency in the control relationship suggesting a need to place } \\
\text { considerable emphasis on communication, relationship-building and } \\
\text { influence. }\end{array}$ \\
\hline $\begin{array}{l}\text { 24. Sharma and Yetton } \\
\text { (2003) }\end{array}$ & $\begin{array}{l}\text { Support should focus on (re)shaping the institutional context e.g. workflow } \\
\text { patterns, procedures, routines, reward systems, control and coordination } \\
\text { mechanisms. Top management support is most appropriate where highly } \\
\text { interdependent tasks are affected. }\end{array}$ \\
\hline
\end{tabular}

Table 9: TMS Research that emphasises user satisfaction through IT projects.

\begin{tabular}{|c|l|}
\hline Author(s) & Prescription(s) for top management \\
\hline $\begin{array}{l}\text { 25. Schmitt and Kozar } \\
\text { (1978) }\end{array}$ & $\begin{array}{l}\text { Be active decision makers (aware of the problem to be solved), and use } \\
\text { project controls, participate in the planning and organisation \& do not defer } \\
\text { naively to the experts }\end{array}$ \\
\hline 26. Emery (1990) & $\begin{array}{l}\text { Be the first initiator, keep close tabs on progress, step in to remove } \\
\text { organizational barriers, display enthusiasm \& publicly declare commitment. } \\
\text { Ensure rapid decision-making and accountability for results. }\end{array}$ \\
\hline
\end{tabular}

Table 10: TMS Research that emphasises technical quality through IT projects. 


\section{APPENDIX 2 - THE INTERVIEW INSTRUMENT INTRODUCTION}

We're taking a fresh look at IT project underperformance and we're looking at developing a Standard(s) to address the issue. [It is reported that around $80 \%$ of large projects fail]

This area has been studied for the last 20-30 years without any significant improvement in results (c.f. construction industry). [We suspect this is mainly because people have looked at it from the project level without enlarging the scope to include organisational factors (outside the immediate project) that must be addressed to realise the benefits of large investments in $I T$ (e.g. BPR).]

We're conducting case studies of IT project - good and bad. It's a sensitive issue but it is important, so [CEO/COO] has agreed that [organisation] should lead the way and participate in the study.

I think it is important to say, that this is completely anonymous. Your name will not be quoted, this is not a witch-hunt and there is no interest in finding blame. We want to develop a Standard to overcome IT underperformance and to do that we have to get into the details of actual projects, find out how they developed, note the things we already do well and understand what things we need to do better. Are you happy this objective?

Sign ethics approval in front of interviewee and give interviewee a copy to give them the opportunity to ask further questions or opt out of the study.

\section{CONTEXT OF QUESTIONS}

Some comment about researchers current understanding of the project being studied (hinting at why it might have been initiated and the other organisational issues at the time).

\section{KEY QUESTION}

How did the project develop and what were some of the key decisions that had to be made? (determining requirements, resourcing, timelines, project management)

\section{PROBE QUESTIONS}

Can you tell us how the ___ project got initiated and what were the benefits expected?

Who were the key players? (e.g. sponsor, initiator, PM, key supporters, key users, unconvinced/opposers, supplier, consultants)

What was achieved /delivered? (in terms of the original benefits desired, scope and budget)

What activities were undertaken in the post-project phase (change requests, ongoing development, training, business process reengineering, any unforeseen activities)?

\section{Project Review}

+ve:

What would you say you did quite well

-ve:

What were the main difficulties you had to overcome?

What areas would you say underperformed?

Why do you think this happened?

\section{Project risk management practices}

If you were to do this again, what would you do differently?

Are there any other significant issues we haven't covered?

Is there anyone else in the organisation who might have a more detailed knowledge on areas you were not close to, or who might have a different perspective of the project? 


\section{REFERENCES}

1. Adams, W. "New Role for Top Management in Computer Applications," Financial Executive (April) 1972, pp 54-56.

2. Akkermans, H., and van Helden, K. "Vicious and virtuous cycles in ERP implementation: A case study of interrelations between critical success factors," European Journal of Information Systems (11:1), Mar 2002 2002, pp 35 - 46.

3. Baccarini, D. "The logical framework for defining project success," Project Management Journal (30:4) 1999, pp 25-32.

4. Bassellier, G., and Pinsonneault, A. "Assessing top management support for information technologies: an new conceptualisation and measure," European conference on information systems, 1998, pp. 1536-1543.

5. Beath, C.M. "Supporting the information technology champion," MIS Quarterly (15:3), September 1991, pp 355-372.

6. Benbasat, I., and Zmud, R.W. "Empirical Research in Information Systems: The Practice of Relevance," MIS Quarterly (23:1) 1999, pp 3-16.

7. Boehm, B.W. "Software Risk Management: Principles and Practices," IEEE Software (Jan) 1991, pp 32-41.

8. Brancheau, J.C., Janz, B.D., and Wetherbe, J.C. "Key Issues in Information Systems Management: 1994-95 SIM Delphi Results," MIS Quarterly (20:2) 1996, pp 225-242.

9. Brandon, D.H. Management Planning for Data Processing Brandon Systems Press, Princeton, New Jersey, 1970, pp. 206-208.

10. BRW "The myth of governance.," in: $B R W, 2003$, pp. 30-36.

11. Brynjolfsson, E., and Hitt, L.M. "Beyond the Productivity Paradox: Computers are the catalyst for bigger changes," Communications of the ACM (41:8) 1998, pp 49-55.

12. Bussen, W.S., and Myers, M.D. "Executive Information System Failure: A New Zealand Case Study," Journal of Information Technology (12:2) 1997, pp 145-153.

13. Checkland, P. Systems Thinking, Systems Practice John Wiley \& Sons, Chichester, 1981.

14. Clegg, C., Axtell, C., Damodaran, L., Farbey, B., Hull, R., Lloyd-Jones, R., Nicholls, J., Sell, R., and Tomlinson, C. "Information technology: a study of performance and the role of human and organizational factors," Ergonomics (40:9) 1997, pp 851-871.

15. Collins, T., and Bicknell, D. Crash: ten easy ways to avoid a computer disaster Simon and Schuster, London, 1997.

16. Cooke-Davies, T. "The "real" success factors on projects," International Journal of Project Management (20) 2002, pp 185-190.

17. Crawford, L. "Senior management perceptions of project management competence," International Journal of Project Management (23:1) 2005, pp 7-16.

18. Currie, W., and Galliers, B. (eds.) Rethinking Management Information Systems. Oxford University Press, New York, 1999.

19. Davenport, T.H., and Markus, M.L. "Rigor vs. Relevance Revisited: Response to Benbasat and Zmud," MIS Quarterly (23:1) 1999, pp 19-23.

20. de Wit "Measurement of project success," International Journal of Project Management (6:3) 1985, pp 164-170.

21. DellaVecchia, T., Scantlebury, S., and Stevenson, J.G. "Three CIO Advisory Board Responses to "Managing the realization of Business Benefits from IT Investments"," MIS Quarterly Executive (6:1) 2007.

22. Delone, W.H. "Determinants of Success for Computer Usage in Small Business," MIS Quarterly (12:1) 1988, pp 51-61.

23. Delone, W.H., and McLean, E.R. "The Delone and McLean Model of Information Systems Success: a ten-year update," Journal of Management Information Systems (19:4) 2003, pp 9-30.

24. Dickson, G.W., Leitheiser, R.L., Wetherbe, J.C., and Nechis, M. "Key Information Systems Issues for the 1980's," MIS Quarterly (8:3) 1984, pp 135-159.

25. Dinter, H. "Criteria for the Organizational Effectiveness of Data Processing," Data Management (9:8), August 1971, pp 33-34.

26. Doll, W.J. "Avenues for Top Management Involvement in Successful MIS Development," MIS Quarterly (9:1), March 1985, pp 17-35. 
27. Doll, W.J., and Vonderembse, M.A. "Forging a Partnership to Achieve Competitive Advantage: The CIM Challenge," MIS Quarterly (11:2), June 1987, pp 205-220.

28. Dvir, D., and Lechler, T. "Plans are nothing, changing plans is everything: the impact of changes on project success," Research Policy (33) 2004, pp 1-15.

29. Eisenhardt, K.M. "Building theories from case studies research," Academy of Management Review (14) 1989, pp 532550.

30. Emery, J.C. "Editors Comments - The Management Difference: a Tale of Two IS Projects," MIS Quarterly (14:1), September 1990, pp xi-xii.

31. Falconer, D.J., and Hodgett, R.A. "The relationship between participation in information systems planning and development and the achievement of performance criteria in Australian commercial organisations that plan strategically for information systems," 10th Australasian Conference on Information Systems, Wellington, New Zealand, 1999.

32. Freeman, G.A.J. "The Role Top Management Must Play in MIS Planning and Implementation," Founders Conference of the Society for Management Information Systems, Society for Management Information Systems, Minneapolis, 1969, p. keynote speech.

33. Garrity, J.T. "Top Management and Computer Profits," Harvard Business Review (41:4), Jul-Aug 1963, pp 6-12, 172174.

34. Goles, T., and Hirschheim, R. "The paradigm is dead, the paradigm is dead...long live the paradigm: the legacy of Burrell and Morgan," Omega (28:3) 2000, pp 249-268.

35. Grindley, K. Managing IT at Board Level: the hidden agenda exposed, (2nd ed.) Pitman, London, 1995.

36. Grover, V., and Kettinger, W.J. "Business Process Change: A reflective view of theory, practice, and implications," in: Framing the Domains of IT Management: projecting the future through the past, R.W. Zmud (ed.), Pinnaflex Educational Resources, Cincinnati, Ohio, 2000, pp. 147-172,433-435.

37. Hampel, R. Committee on Corporate Governance Gee Publishing, London, 1998.

38. Hartog, C., and Herbert, M. "1985 Opinion Survey of MIS Managers: Key Issues," MIS Quarterly (10:4) 1986, pp 351361.

39. Henderson, J.C. "Plugging into strategic partnerships: the critical IS connection," Sloan Management Review (31:3), Spring 1990, pp 7-18.

40. Hewson, J. "Get boards back to basics," in: AFR, 2003, p. 82.

41. Hilmer, F.G. Strictly Boardroom: improving governance to enhance company performance The Business Library, Melbourne, 1993.

42. Hinton, C.M., and Kaye, G.R. "The hidden investments in information technology: the role of organisational context and system dependency," International Journal of Information Management (16:6) 1996, pp 413-427.

43. Huff, S.L., Maher, P.M., and Munro, M.C. "Information Technology and the Board of Directors: Is There An IT Attention Deficit?," MIS Quarterly Executive (5:2) 2006, pp 55-68.

44. Izzo, J. "A View of Tomorrow's System Architecture," in: Embattled Fortress, Jossey-Bass, San Francisco, 1987, p. chapter 6.

45. Jarvenpaa, S.L., and Ives, B. "Executive Involvement and Participation in the Management of Information Technology," MIS Quarterly), June 1991 1991, pp 205-227.

46. Keil, M. "Pulling the plug: Software project management and the problem of project escalation," MIS Quarterly (19:4), Dec 1995 1995, p 421.

47. Keil, M., Cule, P.E., Lyytinen, K., and Schmitt, R.C. "A Framework for Identifyng Software Project Risks," Communications of the ACM (41:11) 1998, pp 76-83.

48. Klein, H.K., and Myers, M.D. "A set of principles for conducting and evaluating interpretive field studies in information systems.," MIS Quarterly (23:1) 1999, pp 67-94.

49. Kohli, R., and Devaraj, S. "Realizing the Business Value of Information Technology Investments: An Organisational Process," MIS Quarterly Executive (3:1) 2004, pp 53-68.

50. KPMG "Global IT Project Management Survey: How committed are you?," KPMG. 
51. Kraemer, K.L., and King, J.L. "Computing and Public Organizations," Public Administration Review (46:6) 1986, pp 488-496.

52. Lane, R.L. "The Key To Managing Information Technology," The Bankers Magazine), April 1985, pp 20-27.

53. Lederer, A.L., and Mendelow, A.L. "Information systems planning: top management takes control," Business Horizons (May-June) 1988, pp 73-78.

54. Lee, A.S. "Rigour and relevance in MIS Research: beyond the approach of positivism alone," MIS Quarterly (23:1) 1999, pp 29-34.

55. Lucas, H.C. Why Information Systems Fail Columbia University Press, New York, 1975.

56. Luftman, J., Kempaiah, R., and Nash, E. "Key Issues for IT Executives 2005," MIS Quarterly (5:2) 2006, pp 81-99.

57. Luftman, J., and McLean, E.R. "Key Issues for IT Executives," MIS Quarterly (3:2) 2004, pp 89-104.

58. Lyytinen, K. "Different Perspectives on Information Systems: Problems and Solutions," ACM Computing Surveys (19:1) 1987, pp 5-46.

59. Mähring, M. "IT Project Governance: a process-oriented study of organizational control and executive involvement," Stockholm School of Economics, Stockholm.

60. Markus, L.M. "Implementation Politics: Top Management Support and User Involvement," Systems, Objectives, Solutions (1) 1981, pp 203-215.

61. Markus, L.M. "Change Agentry - the next IS frontier," MIS Quarterly (Dec) 1996, pp 385-407.

62. Markus, L.M. "Toward an integrated theory of IT related risk control," IFIP TC8 WG8.2 International Working Conference on the Social and Organizational Perspective on Research and Practice in Information Technology, Kluwer, Aalborg, Denmark, 2000, pp. 167-178.

63. Markus, L.M., and Keil, M. "If we build it they will come: Designing information systems that people want to use," Sloan Management Review (35:4) 1994, pp 11-25.

64. Markus, M.L., Axline, S., Petrie, D., and Tanis, C. "Learning from adopters' experience with ERP: problems encountered and success achieved," Journal of Information Technology (15) 2000, pp 245-265.

65. McGolpin, P., and Ward, J. "Factors Influencing the Success of Strategic Information Systems," in: Information Systems: an emerging discipline?, J. Mingers and F. Stowell (eds.), McGraw-Hill, London, 1997, pp. 287-327.

66. Morton, G.H.A. "Become a project champion," International Journal of Project Management (1:4) 1983, pp 197-203.

67. Nelson, R.R. "IT Project Management: Infamous Failures, Classic Mistakes, and Best Practices," MIS Quarterly Executive (6:2) 2007, pp 67-78.

68. O'Toole, R.J.W., and O'Toole, E.F. "Top Executive Involvement in the EDP Function," Management Controls (Peat Marwick Mitchell \& Co) (June) 1966, pp 125-127.

69. Peppard, J., Ward, J., and Daniel, E. "Managing the Realization of Business Benefits from IT Investments," MIS Quarterly Executive (6:1) 2007.

70. Perry, C. "Processes of a case study methodology methodology for postgraduate research in marketing," European Journal of Marketing (32:9/10) 1998, pp 785-802.

71. Poon, P. "Critical success factors revisited: Success and failure cases of information systems for senior executives," Decision Support Systems (30:4), Mar 2001 2001, p 393.

72. Rangananathan, C., Watson-Manheim, M.B., and Keeler, J. "Bringing Professionals on Board: Lessons on Executing ITEnabled Organizational Transformation," MIS Quarterly Executive (3:3) 2004, pp 151-160.

73. Reich, B.H., and Benbasat, I. "An empirical investigation of factors influencing the success of customer-oriented strategic systems," Information Systems Research (1:3), September 1990, pp 325-347.

74. Rocheleau, B. "Prescriptions for Public-Sector Information Management: a Review, Analysis and Critique," American Review of Public Administration (30:4), December 2000 2000, pp 414-435.

75. Rochleau, B. "Prescriptions for Public-Sector Information Management: a Review, Analysis and Critique," American Review of Public Administration (30:4), December 2000 2000, pp 414-435.

76. Rockart, J.F. "The line takes the leadership - IS management in a wired society," Sloan Management Review (29:4), Summer 1988, pp 57-64. 
77. Rockart, J.F., and Crescenzi, A.D. "Engaging Top Management in Information Technology," Sloan Management Review:Summer 1984) 1984, pp 3-16.

78. Rockwell, W.P. "MIS: A View from the Top," Duns Review (92:4) 1968, pp 20-22.

79. Sauer, C. Why Information Systems Fail: a case study approach Alfred Waller Ltd, Henley on Thames, 1993.

80. Sauer, C. "Deciding the Future for IS Failures Not the Choice You Might Think," in: Rethinking Management Information Systems, B. Galliers and W. Currie (eds.), Oxford University Press, New York, 1999.

81. Schmidt, R., Lyytinen, K., Keil, M., and Cule, P. "Identifying Software Project Risks: An International Delphi Study," Journal of Management Information Systems (17:4) 2001, pp 5-36.

82. Schmitt, J.W., and Kozar, K.A. "Management's role in information system development failures: a case study," MIS Quarterly (June) 1978, pp 7-16.

83. Seddon, P.B., Graeser, V., and Willcocks, L. "Measuring Organizational IS Effectiveness: An Overview and Update of Senior Management Perspectives," Database for Advances in Information Systems (33:2), November 1999 2002, pp 1128.

84. Seddon, P.B., Staples, D.S., Patnayakuni, R., and Bowtell, M. "Dimensions of Information Systems Success," Communications of the Association for Information Systems (2:20), November 1999 1999, pp 1-61.

85. Sharma, R., and Yetton, P. "The contingent effects of Management Support and Task Interdependence on successful information systems implementation," MIS Quarterly (27:4) 2003, pp 533-555.

86. Smyrk, J.R. "Why most "IT Projects" are really IT without the project," 3rd World Project Management Conference, Gold Coast, Australia, 2002.

87. Soh, C., and Markus, M.L. "How IT Creates Business Value: A Process Theory Synthesis," the Sixteenth International Conference on Information Systems, Amsterdam, The Netherlands, 1995, pp. 29-41.

88. Standards Australia HB280 How Boards and Senior Management Have Governed ICT Projects to Succeed (or Fail) Standards Australia, Sydney, 2006.

89. Standish "Unfinished voyages: a follow-up to the CHAOS report," The Standish Group, 1996.

90. Standish "CHAOS," The Standish Group, West Yarmouth, MA.

91. Standish "Latest Standish group CHAOS Report shows Project Success Rates Have Improved by 50\%," The Standish Group, West Yarmouth, MA.

92. Strassmann, P.A. The Politics of Information Management Information Economics Press, New Canaan, CT., 1995.

93. Tashakkori, A., and Teddlie, C. (eds.) Handbook of Mixed Methods in Social and Behavioural Research. Sage, Thousand Oaks, 2003.

94. Thomas, J., Dellisle, C.L., Jugdev, K., and Buckle, P. "Selling Project Management to Senior Executives: The Case for Avoiding Crisis Sales," Project Management Journal (33:2) 2002, pp 19-28.

95. Thomsett, R. Third Wave Project Management Prentice-Hall, Englewood Cliffs, 1989.

96. Ward, J., Taylor, P., and Bond, P. "Evaluation and realisation of IS/IT benefits: an empirical study of current practice," European Journal of Information Systems (4) 1996, pp 214-225.

97. Willcocks, L., and Margetts, H. "Risk assessment and information systems," European Journal of Information Systems (3:2) 1994, pp 127-138.

98. Yardley, D. Successful IT project delivery: learning the lessons of project failure Addison-Wesley, London, 2002.

99. Yin, R.K. Case Study Research: design and methods, (3rd ed.) Sage, Newbury Park, 2003.

100. Young, R. "Estimating the value of IT Project Governance," Inaugural international Research Workshop on Information Technology Project Management (IRWITPM), a Special Interest Group of the International Conference for Information Systems Association of Information Systems, Milwaukee, WI, 2006a.

101. Young, R. "What is the ROI for IT Project Governance? Establishing a benchmark.," 2006 IT Governance International Conference, Auckland, New Zealand, 2006b.

102.Young, R.C. "The role of the board, senior management and IT governance in IT success and failure," PACIS doctoral consortium, Adelaide, 2003. 
103. Young, R.C., and Jordan, E. "IT Governance and Risk Management: an integrated multi-stakeholder framework," Asia Pacific Decision Sciences Institute, Bangkok, Thailand, 2002a.

104. Young, R.C., and Jordan, E. "Lifting the Game: Board views on e-commerce risk," IFIP TG8.6 the adoption and diffusion of IT in an environment of critical change, Pearson Publishing Service, Sydney, 2002b, pp. 102-113.

105.Young, R.C., and Jordan, E. "Passion and IT Governance: two case studies reveal why and how senior management should support IS projects," PACIS, Adelaide, 2003. 